\title{
Az egészségügy és a mágikus gondolkodás viszonya
}

\author{
Györfi András dr.
}

Margittai Városi Kórház, Marghita, jud. Bihor, Romania

\section{Történelmi áttekintés}

Olybá tűnhet sokaknak, hogy mióta Könyves Kálmán törvénybe adta, hogy boszorkányokról, lidércekről többet szó ne essen - mivelhogy nincsenek -, a kuruzslók problémája is megoldódott. (1110-ben, a tarcali országgyúlés I. törvénykönyve 57. paragrafusa szerint: „De strigis, vero quae non sunt, nulla questio fiat!”). Merthogy sokan úgy vélik, hogy e két iparág képviselői tekintetében egy kalap alá vehető szemfényvesztésről vagy megtévesztésról van szó. Pedig a boszorkányok és kuruzslók között van egy lényeges különbség. Kálmán királyunk azért adta ki nevezetes rendeletét, mert szkeptikus volt azoknak a túlvilági, a gonosszal szövetkezett erőknek a létezésében, amelyeknek az állítólagos boszorkányok elkötelezték volna magukat. De más a helyzet a kuruzslókkal. Ők igenis léteznek, csak nem a természetfelettivel szövetkeznek, hanem az emberek mágikus gondolkodásmódjának előhívásával hálózzák be áldozataikat. És szerintem tanult királyunknak igaza volt a túlvilági erőkkel kapcsolatban: ezek valóban kitalált dolgok, az ismeretlentől való félelem következményeként kerültek be a köztudatba. Ezzel szemben a mágikus gondolkodásmód egy archaikus mentális állapot velejárója, amely minden különösebb probléma nélkül fennmaradt modernnek nevezett korunkban. Tudta ezt a király is, ezért a fent nevezett törvénykönyv 60. paragrafusa így szól: „Malefici per nuncium archidiaconi et comitis inventi iudicentur!”, vagyis: „A varázslókat (kuruzslókat), akiket az esperes és az ispán találnak, ítéljék el!”

A kuruzslás természetesen sokkal korábban is ismert jelenség volt, és hiába lépett fel ellene a törvény szigora az ókor óta, létezik manapság is. Ráadásul jelentős hatása volt és van a mindenkori egészségpolitikára. A kuruzslás kialakulása tehát a mágikus gondolkodásmódhoz kapcsolódik, ezért megjelenésének, fejlődésének oka valahol mélyen, a neurobiológiai evolúciónk korai történelmének homályában keresendő. Ráadásul a szimbólumok ereje, múködése sokkal hamarabb megragadja a gyerekek intellektusát, minthogy a cseperedő elméjü emberpalánta olvasni tudna. Mire az olvasás és nevelés révén a kritikai gondolkodásmód kialakulna, a mágikus gondol- kodásmód már befészkelte magát a gyerek kobakjába, és ez az egyik leggyakoribb oka a fiatalkori konfliktusoknak. Mind mondhatja a magáét a tanító néni/bácsi az induktív vagy deduktív gondolkodás barázdájába próbálván beállítani a kis nebulót, ha az már tündérmeséken vagy bugyuta rajzfilmeken hozzáedződött a színészek hangján beszélő állatok vagy túlvilági lények mindennapos felbukkanásához. Valószínúleg jelentős szerepe lehet a személyiségzavarok kialakulásában ennek a konfliktusnak, amelyet a mesevilág és a való világ közötti átjárás vált ki. A gyerekek hajlamosabbak ugyanis a mágikus gondolkodásmód alapján értelmezni a dolgokat, és amikor nevelésük során azzal szembesülnek, hogy az addigi mesemondók átállnak a másik táborba, megpróbálván őket meggyőzni, hogy kilépjenek a mesevilágból, az egy nagyon nehéz periódus. Rejtett módon ugyan, de a gyerekek jelentős hányada továbbra is ragaszkodni fog a csodavárás stratégiájához, és felnőttkorba érve, döntéshozatali helyzetekben emiatt sokszor irracionális módon reagálnak. És ez érvényes egy betegség felbukkanása esetén is.

\section{A mágikus gondolkodásmód jellemzői}

A mágia szó eredete indo-európai gyökerű: az avesztáni (kelet-iráni) nyelven magauno-nak nevezték a Méd Birodalom tudós papjait - már az i. e. V. évszázad előtt. A fogalom Hérodotosz közvetítésével került át a görög nyelvbe a mágosz (többes szám: mágoi) formában, az i. e. V. században, innen a latinba, majd az újlatin nyelvekbe. A szó jelentése: „összefüggések, megfelelések, hasonlóságok, hierarchiák, vonzalmak és ellenszenvek - magyarul a természetes és a természetfeletti törvények - felhasználása valamilyen cél érdekében" [1]. Véleményem szerint a mágikus gondolkodásmód gyökere éppen ezzel a céllal kapcsolatos: a fent nevezett törvények felhasználásának célja ugyanis a társadalmi hierarchián való előrehaladás, illetve a felhasználó kiváltságainak megerősítése. Ez a felismerés lehet a Claude Lévi-Strauss által megfogalmazott neolitikus paradoxon megoldása is: a strukturális antropológia atyja szerint a kőkorszaki ember már komoly tudományos ismeretekkel 
rendelkezett (földmû́velés, állatidomítás, szövés, fazekasság stb.), ennek ellenére őseink nem állították szembe a mágiát a tudománnyal, hanem a megismerés két párhuzamos, majdnem egyenértékú módozatának tekintették [2]. A két gondolkodásmód között az a lényeges különbség, hogy a kritikai gondolkodásmód a környezet elemeinek és a közöttük levő fizikai jellegú kölcsönhatásoknak az ismeretét feltételezi, amelyek adott esetben akár roppant bonyolultak is lehetnek. Ezek (akár részleges) ismeretében a gondolkodó ember helyesen határozhatja meg az ok-okozati összefüggéseket, felmérheti helyzetét és a jövőbeli történések valószínúségét. Ennek alapján van esélye befolyásolni a kialakulófélben levő eseményeket - és így nyerte el a tudás társadalomformáló szerepét [3]. Ezzel szemben a mágikus gondolkodásmód eltekint a fizikai kölcsönhatások tanulmányozásának embert próbáló, kitartást és intellektuális munkát igénylő feladatától. Helyette néhány egyszerü elvet alkalmaz a dolgok és események közötti kapcsolatok magyarázására, mint például

- a hasonlóság elve: például a dió az agy bántalmainak, a bab pedig a vese bántalmainak a kezelésére alkalmas - mert ezeknek a növényi részeknek az alakja hasonlít ezekhez az emberi szervekhez;

- a ragályosság elve: miszerint egymással valamikor érintkezett dolgok között megmarad valamiféle energiaszerú vagy informatikai kapcsolat, amelyet a tudomány sem kimutatni, sem megmagyarázni nem tud, mégis „múködik” - megfelelő közbenjárás hatására;

- a ködösítés elve: valamely fizikai kölcsönhatás bizonyos elemeit felhasználva egy olyan áltudományos rendszer kidolgozása, amely elkápráztatja a leendő áldozatot;

- az alárendeltség elve: egy mindenható, fensőbb rendú - de beavatatlanok számára láthatatlan - entitás léte, aki a tudomány számára megmagyarázhatatlan módon befolyásolni képes az események vagy folyamatok kimenetelét. Ezen az entitáson keresztül sokan megpróbálják befolyásoltatni a dolgok állását, majd, ha ez nem sikerül, jöhet a hisztéria, agresszió, depresszió stb. vagy egy profi közbenjáró felkeresése, aki majd elvállalja a kapcsolat létrehozását a fent említett entitással. Ez a fajta mágikus gondolkodásmód tehát sokkal könnyebben megérthetó, elfogadható a kisgyerekek számára, valamint azon felnőttek számára, akik valamilyen oknál fogva hadilábon állnak a kritikai gondolkodásmód kialakulását elősegítő tudományok elsajátításával. Ám csupán ennek alapján nem lehet egyértelmúen eldönteni, hogy melyik gondolkodásmód a helyes. Mindkét kategória képviselője lesajnáló szánakozással tekint a másikra: az egyik a hitet hiányolja a másikból, a másik pedig a tudást.

Hogy a mágikus gondolkodásmód miért marad fenn továbbra is, miután a tudományos és kritikai gondolkodásmód általánosan elfogadottá vált a nyugati civilizációkban, azzal lehet kapcsolatos, hogy nem is olyan egyszerú eldönteni, hogy kinek van igaza. Végül is a gondolkodásmód helyességének megállapításához az il- letőnek azt a képességét kellene felmérnünk, hogy milyen mértékben tudja a jövőbeli eseményeket befolyásolni. A kritikai gondolkodásmód révén az emberiség olyan szerkezeteket tervezett és épített meg, amelyek idegen égitesteken tervezett módon leszálltak és múködtek, vagy amelyek képesek egy embert sakkban legyőzni. Ez a fajta gondolkodásmód egyes fertőző betegségek felszámolásához vagy a munka termelékenységének nagymértékü fokozódásához vezetett. Úgy tünhet, hogy a kritikai gondolkodásmód révén az Ember önkezébe vette a sorsát, maga alakíthatja környezetét és jövőjét.

Ennek ellenére sokan úgy vélik, hogy a Homo sapiens nem alkalmas a sorsát kormányozni, csak valamiféle csoda és túlvilági gondviselés révén valósulhat meg túlélésünk. És valóban, a klímaváltozás vagy a nukleáris háború veszélye olyan fenyegetéseknek minősülnek, amelyek megkérdőjelezhetik fajunk fennmaradását - és amelyek kialakulásában a kritikai gondolkodásmódnak döntő szerepe volt. A mágikus gondolkodásmód hívei úgy vélik, hogy az ember sorsát egy rejtett erő, egy felsőbbrendü hatalom igazgatja, amelynek céljait, szándékait az ember föl nem foghatja. Ezért ők nem a természet törvényeit és kölcsönhatásait próbálják megfigyelni és megérteni, hanem ennek a természetfeletti entitásnak a pártfogását keresik, és megpróbálnak úgy eljárni, ahogy feltételezésük szerint tettük elnyerné ennek az entitásnak a kegyeit. Ennek a gondolkodásmódnak egyes képviselői meggyőzhetnek bizonyos csoportokat, hogy az ő személyük/csoportjuk kedvezményezett kapcsolatban van ezzel az entitással, és ekképpen ők a legfelsőbb hatalom tudtával, jóváhagyásával, sőt akár a kifejezett utasítására fejthetnek ki valamilyen hatást az illetó csoportra. Ekképpen a mágikus gondolkodásmód is nagymértékben képes embertömegek jövőjét befolyásolni: gondoljunk csak a vallási háborúkra, amelyek végigkísérték napjainkig az emberiség történelmét, a több millió embert útnak indító zarándoklatokra, a mostanában aktuális, vallásos alapú terrortámadásokra stb. És végül a kuruzslók is ebbe a kategóriába tartoznak, akik elhitetik áldozataikkal, hogy olyan képességeknek vannak a birtokában vagy olyan gyógyítóeróket tudnak a szolgálatukba állítani, amelyeknek nincs tudományos alapja.

\section{A kuruzslás jogi helyzete}

Manapság a Büntető Törvénykönyv 187. paragrafusa a kuruzslást az orvosi gyakorlat körébe tartozó tevékenység jogosulatlan kifejtéseként értelmezi, vagyis gyakorlatilag csak egy engedélyköteles tevékenység engedély nélküli végrehajtásának tekinti. És abban valóban igaza van a törvényhozónak, hogy modernnek nevezett korunkban helytelen lenne a gondolkodásmódja okán valakit a bíróságnak elmarasztalnia. Volt rá példa régen - nemcsak Kálmán király törvénykönyvében, hanem említhetném például Roberto Bellarmino bírónak egy 1633-ban hozott döntését bizonyos Galilei Galileo elítélt ügyében [4]. Ezt a tudóst ugyanis azért ítélték el (szobafogságra 
és tanainak visszavonására), mert a Szentírás által említett geocentrikus világkép helyett a heliocentrikus modellt vélte valósnak. Ez a bíboros annak ellenére meghozta történelmi ítéletét, hogy 1600-ban a szintén általa máglyahalálra ítélt Giordano Bruno - aki a kritikai gondolkodásmód elkötelezettjeként maga is a geocentrizmus elavultságáról értekezett, az égen látható csillagokat a mienkhez hasonló napoknak tartotta, amelyek körül életet fenntartó bolygók keringenek stb. - ezekkel a szavakkal fogadta az ítélet kihirdetését: „Maiori forsan cum timore sententiam in me fertis quam ego accipiam" ( „Lehet, hogy nektek, akik ítéletet hoztok, több okotok van a félelemre, mint nekem, aki elszenvedem azt") [5].

Hogy az inkvizíció hibáit meg ne ismételhesse, a mai Btk. nem tekinti büncselekménynek a mágikus gondolkodásmódban gyökerező, tudatos vagy téveszméken alapuló gyógyítási eljárásokat, ha azok nem tartoznak az orvosi gyakorlat körébe. Ezért cikkemben a kuruzslás egy általánosabb, régiesebb értelmezését fogom használni. Hisz a jelenség jóval a Btk. megszületése előtt létezett: a szó maga a „kúra” (a latin cura, kezelés) és a szláv eredetű „varázslás” elemeinek összevonásával alakulhatott ki. Ekképpen azoknak a tevékenységeknek egy részét fogom elemezni, amelyek emberi szenvedésekre olyan eljárásokkal próbálnak megoldást nyújtani, amelyeket a hagyományos nyugati orvosi gyakorlat nem használ - és amelyek hatásmechanizmusa a mágikus gondolkodás valamelyik elvén alapul.

\section{A mágikus gondolkodáson alapuló kuruzslások formáiról}

A legtöbb ellentmondás az akupunktúra megítélése körül folyik. Egy több ezer éve dokumentált, távol-keleti eredetű eljárásról van szó, amely az életenergiáknak a meridiánok mentén történő áramlásának túkkel való befolyásolásán alapul. A Huang Ti nej-csing (A Sárga Császár belső könyvei) eredeti változatai több mint kétezer évesek - habár maga a Sárga Császár egyes kínai történészek szerint a Han-dinasztia tagjaként i. e. 2697-től 2597-ig uralkodott. A szöveggyújtemény szerzői ismeretlenek, ők említik először a kínai világszemléletre jellemző yin és yang, tao és csi fogalmak rendszerét, amelyek szerintük meghatározzák az emberek egészségét [6]. A modern tudományos eljárások azonban sem az életenergia, sem a meridiánok létezését nem erősítették meg. Ennek ellenére klinikai vizsgálatok bizonyítják, hogy bizonyos - meglehetősen korlátozott számú - ártalmak, panaszok esetében az akupunktúra valóban enyhülést hoz. Pontosabban az Egészségügyi Világszervezet 28 olyan betegséget és állapotot nevezett meg, amelyek esetében az akupunktúra hasznosnak bizonyult [7]. A további vizsgálatok lendületüket vesztették azonban, amikor nyilvánvalóvá vált, hogy az akupunktúra „divatját” Mao Ce-tung kínai főtitkár kezdte terjeszteni 1949 után [8], amikor rájött, hogy népének nincs elegendő számú jól képzett orvosa. Ebben a kényszerhely- zetben hozta meg azt a döntését, hogy akkor a régi kínai orvosi dokumentumokat tudományos értékúeknek kell nyilvánítani. 1950-ben Zhu De elvtárs tolmácsolta Mao Ce-tung üzenetét: „Chinese acupuncture treatment has a history of thousands of years. It is not only simple and economical, but is also very effective for many kinds of diseases. So this is the science” („A kinai akupunkturás gyógyitás több évezredes múltra tekint vissza. Nemcsak egyszerü és gazdaságos eljárás, hanem nagyon hatásos is számos betegség esetén. Tehát ez a tudomány”) [9]. Bár sehol a világon diktátor még nem változtatott meg tudományos álláspontokat (állítólag még Galilei is a szakállába dörmögte, hogy „Eppur si muove”, miután Bellarmino bíboros kihirdette az ítéletet), ezúttal mintha valami mégis másként történt volna. És nemcsak Kínában, ahol Mao elnök szava parancs volt: az Egyesült Államokban és Európában is egyre inkább elterjedt az alternatív medicina, amelynek zászlóshajója az akupunktúra volt. Sok vita folyt arról a hatásmechanizmusról, amely révén az akupunktúra kifejthette hatását [10], a legfrissebb kutatások például az adenozin szerepét mutatták ki [11]: a túnek a Zusanli pontban való megfelelő manipulálása esetén a szövetközi nedvben az adenozin helyi koncentrációjának növekedését mutatták ki - ami fájdalomcsillapító hatású.

Mao elnök ezzel a húzásával több legyet ütött egy csapásra. A népnek az a része, amely túlélte a Nagy Ugrást (1959-1961 között 45 millióra volt tehető azoknak a kínaiaknak a száma, akik éhen haltak az eróltetett iparosítás következtében [12]), pár éven belül elégedetten észlelhette, hogy vezetőjük gondoskodott számukra megfelelő számú gyógyítóról. Persze sem Mao, sem a kínai elit nem használta az akupunktúrát. A Szovjetunió, az Egyesült Államok és az európai országok sorban állva esdekeltek, hogy megtanulhassák a kínai csodamódszert: Kína hirtelen tudományos nagyhatalom lett a világ szemében. De a legérdekesebb, hogy egy magát kommunistának nevező ország hivatalossá tette a mágikus gondolkodásmódot és a kuruzslás egy formáját támogatta a tudományos alapokra támaszkodó orvoslás helyett. Mert tisztázzuk: az eddig elvégzett valódi tudományos kutatások az akupunktúra hatásmechanizmusát illetően nem erősítették meg azt a tündérmesét, hogy a 20 meridiánban valamiféle életenergia keringene. És bár a nyugati medicina nagy tisztelettel tekint Hippokratészra, azt nem azért teszi, mert a kószi orvos a négy testnedv keringésének zavarában kereste a betegségek okát, hanem azért, mert a beteg és környezete alapos megfigyelésére alapozta döntéseit, és az erkölcsi tisztaság fontosságát hangsúlyozta. És ne feledjük, hogy ez az európai orvos a 80. olümpiász első évében született (azaz i. e. 460-ban) - vagyis több mint két évszázaddal a Huang Ti nej-csing megírása előtt! Tehát Mao legnagyobb ideológiai nyeresége abban állt a mágikus gondolkodásmód támogatása révén, hogy megerősített egy olyan hitet az emberekben, miszerint a tudományos gondolkodás felett van egy ősi, rejtett, a beavatottak számára fenntartott tudás (amelyet ő a köznép rendelkezésére bocsátott - mint annyi más 
kínai császár előtte). A köznép pedig köszönettel vette a kegyet - Kínában és világszerte. De a kezelések során beléjük szúrt tû nemcsak a fájdalmukat enyhítette, hanem a kritikai gondolkodásmód alkalmasságába vetett hitüket is csökkentette. Márpedig a csodákra váró ember türelmesebb a többieknél, mert a csodákra általában sokáig kell várni. Nagyon, nagyon sokáig... Valószínúleg ezért támogatja sok nagyhatalom $m a$ is az akupunktúra elterjedését, a horoszkópok rendszeres közlését: türelmes, csodaváró emberek jobban bírják a hatalom packázását, mint a kritikai gondolkodás hívei.

A homeopátia esetében szintén a mágikus gondolkodásmód érhető tetten - ebben az esetben Samuel Hahnemann német orvos által 1796-ban kitalált „Similia similibus curentur", vagyis a hasonlóság elve érvényesül, miszerint egy betegséget az a szer gyógyít meg, amely nagy adagban az egészséges embernél a betegség tüneteit kiváltja. Ezeket a szereket aztán a homeopaták addig hígítják és ütögetik egy bőrbe kötött vaskos könyvhöz, amíg az oldatban egyetlen eredeti molekula sem marad abból a szerból, amely a betegséget okozta volna. A kuruzsló szerint azonban az oldat ekként is megőrzi az ártalmas anyag rezgésmintázatát, és ez az információ a beteget képes lesz meggyógyítani. Az eljárás a placebóhatás révén valóban hozhat eredményeket bizonyos esetekben, hisz a homeopata orvos részletesen kikérdezi a beteget, majd pontosan előírja a szerek használatát - és már önmagában ez a procedúra segíthet néhány betegség tüneteinek esetében. Az Avogadro-számot meghaladó hígítású oldat molekuláinak rezgésében archivált információmintázatok nélkül is.

A biorezonancia szintén elterjedt módszerré vált az alternatív medicina kínálatában, amely a ködösítés elvén fejlődött ki. A németországi, a szcientológiával kacérkodó Franz Morell és veje, a mérnöki képesítéssel rendelkező Erich Rasche állította elő 1977-ben a bőr ellenállását merő szerkezet módosításából az első MORA-terápiás készüléket (neveik kezdőbetűiből). Állítólagos hatásmechanizmusának magyarázatában a leendő áldozatok biofizikai ismereteinek hiányára alapoztak: leegyszerűsítve a kóros, diszharmonikus frekvenciákat elvezetik a testből, a meggyengült egészséges rezgéseket pedig felerősítik. A diszharmónia pontos mibenléte persze kérdéses. Mindezt manapság már ámulatba ejtő, futurisztikus látványt nyújtó monitorokon és színes diagramokon mutatják be a betegeknek. Ám a módszer hatásossága alig éri el a placebóét.

A bioenergetikai gyógyítás már az alárendeltség és a ködösítés elvén alapszik. A reiki esetében az alárendeltségról maga az alapító nyilatkozott: 1922-ben Uszui Mikao háromheti elvonulás után, amelyet böjtöléssel és imádkozással töltött, misztikus kinyilatkoztatás részese lett, amely után képesnek érezte magát más emberek életenergiája áramlásában keletkezett zavarok javítására. Eredetileg kézrátétellel, de aztán a ködösítés bevezetésével egyes követői már távgyógyításra is vállalkoznak a ragályosság elvének alkalmazásával.

\section{Az alternatív medicina térnyerésének okairól}

Fölvetődhet tehát a kérdés, hogy mennyire elterjedt manapság az egészségügyi ellátásban az alternatív medicina. Pontos felmérések nincsenek ugyan, mert sokan nem vallják be, hogy kuruzslókhoz fordulnak panaszaikkal de valószínú, hogy az emberek több mint fele fordult már élete során az alternatív medicina valamilyen formájához. Ennek a nagy népszerüségnek az oka többrétü: - A jelenleg hatályos Btk., szemben Könyves Kálmán I. törvénykönyvével, nem tiltja az alternatív medicina fent megnevezett ágainak iparszerû űzését. Sőt azt sem írja elő, hogy hirdetéseiken ezek a szolgáltatók kötelesek tájékoztatni a közönséget, miszerint az általuk ajánlott eljárásoknak nincs tudományos alapja. Ezt kihasználva aztán a szolgáltatók olyan áltudományos reklámmal csalják lépre a betegeket, amilyet a fantáziájuk megenged.

- A jelenleg alkalmazott, bizonyítékokon alapuló orvostudomány kommunikációs zavarban van. Egyrészt a diagnosztika és a terápia annyira bonyolult mechanizmusok révén múködik, amit már nehéz az átlagembernek elmagyarázni; másrészt a nyilvánosságra juttatott kutatások sokszor egymásnak ellentmondó eredményekről számolnak be vagy törvénytelenségekrôl. Amit a szenzációhajhász média előszeretettel vesz górcső alá: a tekintély megtépázása mindig emeli a nézettségi indexeket.

- A hagyományos orvoslás gyógyszerei sokszor drágák vagy mellékhatásaik lehetnek. Bizonyos eljárásokra hosszú várólistára kell feliratkozni.

- A hagyományos orvosnak kötelessége tájékoztatni a beteget, ha gyógyíthatatlan betegséget tapasztal. Ebben az esetben is sokan egyéb gyógymódokhoz fordulnak.

- A megerősítés utáni vágy is jelentős szerepet játszhat: ha valaki fordult már kuruzslóhoz, és túlélte, gyakran ajánlja majd ismerôseinek is ezt az izgalmas kalandot - mert ha tettét ismerősei követik, megerősítik benne, hogy helyesen döntött.

- Egyes emberek világképe vagy az egészségről és betegségekről kialakult képe hasonlíthat valamelyik alternatív gyógymódot alkalmazó szolgáltató által közvetített áltudományos fogalomhálóhoz - ezek az emberek gyakrabban fordulnak ezekhez a szolgáltatókhoz. Erról olvashatunk Zörgö-Purebl-Zana közelmúltban megjelent közleményében [A komplementer és alternatív medicina felé orientálódó terápiaválasztást meghatározó tényezők. Orv. Hetil., 2016, 157(15), 584592.]

- Tudatlanság: az áltudományos szövegek értelmezése és a bennük rejlő érvelési hiba megtalálása nem egyszerú intellektuális feladat mindenki számára.

- A placebóhatást többször említettük a cikk során.

- Sok betegség meggyógyul magától is (enyhe fertőző betegségek, traumák stb.) - pontosabban a szervezet 
önjavító és védekező mechanizmusai múködésbe lépnek. Ilyenkor aztán az alternatív medicina tényleg „csodákat” tehet.

- Kapzsiság. Sok alternatív gyógyászati szolgáltató busás hasznot szerez tevékenysége révén, amelyet legálisnak tekint - mivel adót fizet. És a Btk. nem bünteti.

\section{Irodalom}

[1] Magyar, L. A.: Magia naturalis. [Magia naturalis.] Kairosz Kiadó, Budapest, 2005, p. 7. [Hungarian]

[2] Lévi-Strauss, C.: The savage mind. [La Pensée Sauvage.] Librairie Plon, Paris, 1962, pp. 21-25. [French]

[3] Györfi, A.: Mysterious physics. [Rejtélyes fizika.] Kossuth Kiadó, Budapest, 2012, pp. 12-17. [Hungarian]

[4] Machamer, P.: Galileo Galilei. In: Stanford Encyclopedia of Philosophy. (Winter 2014 Edition. Principal Editor: E. N. Zalta.) Available from: http://plato.stanford.edu/archives/win2014/ entries/galileo/>

[5] Hesemann, M.: The black legends. Chapter XVI, Giordano Bruno. [Sötét alakok. XVI. fejezet, Giordano Bruno.] Szent István Társulat, 2010. Available from: http://seraphin.hu/btk/ egytex/alak.pdf [Hungarian]
[6] Tokaji, Zs.: The Yellow Emperor's Classic of Internal Medicine - Elementary Questions, Huang Di nei jing - Su wen. [A Sárga Császár belső könyvei - Egyszerü kérdések.] Fapadoskonyv.hu, Budapest, 2010. [Hungarian]

[7] World Health Organization: Acupuncture: review and analysis reports on controlled clinical trials. Geneva, 2003. Available at http://apps.who.int/iris/handle/10665/42414

[8] Taylor, K.: Chinese medicine in early communist China, 19451963: A medicine of revolution (Needham Research Institute Series). Routledge, New York, 2005.

[9] Xinnong, C.: Chinese acupuncture and moxibustion. Foreign Languages Press, Beijing, 1987, pp. 6-10.

[10] Chon, T. Y, Lee, M. C.: Acupuncture. Concise review for clinicians. Mayo Clin. Proc., 2013, 88(10), 1141-1146.

[11] Takano, T., Chen, X., Luo, F., et al.: Traditional acupuncture triggers a local increase in adenosine in human subjects. J. Pain, 2012, 13(12), 1215-1223.

[12] Meng, X., Qian, N., Yared, P.: The institutional causes of China's Great Famine, 1959-1961. Review of Economic Studies, 2015, 82(4), 1568-1611. Available at https://www0.gsb.columbia. edu/faculty/pyared/papers/famines.pdf

(Györfi András dr., e-mail: andrasgy@rejtelyesfizika.hu)

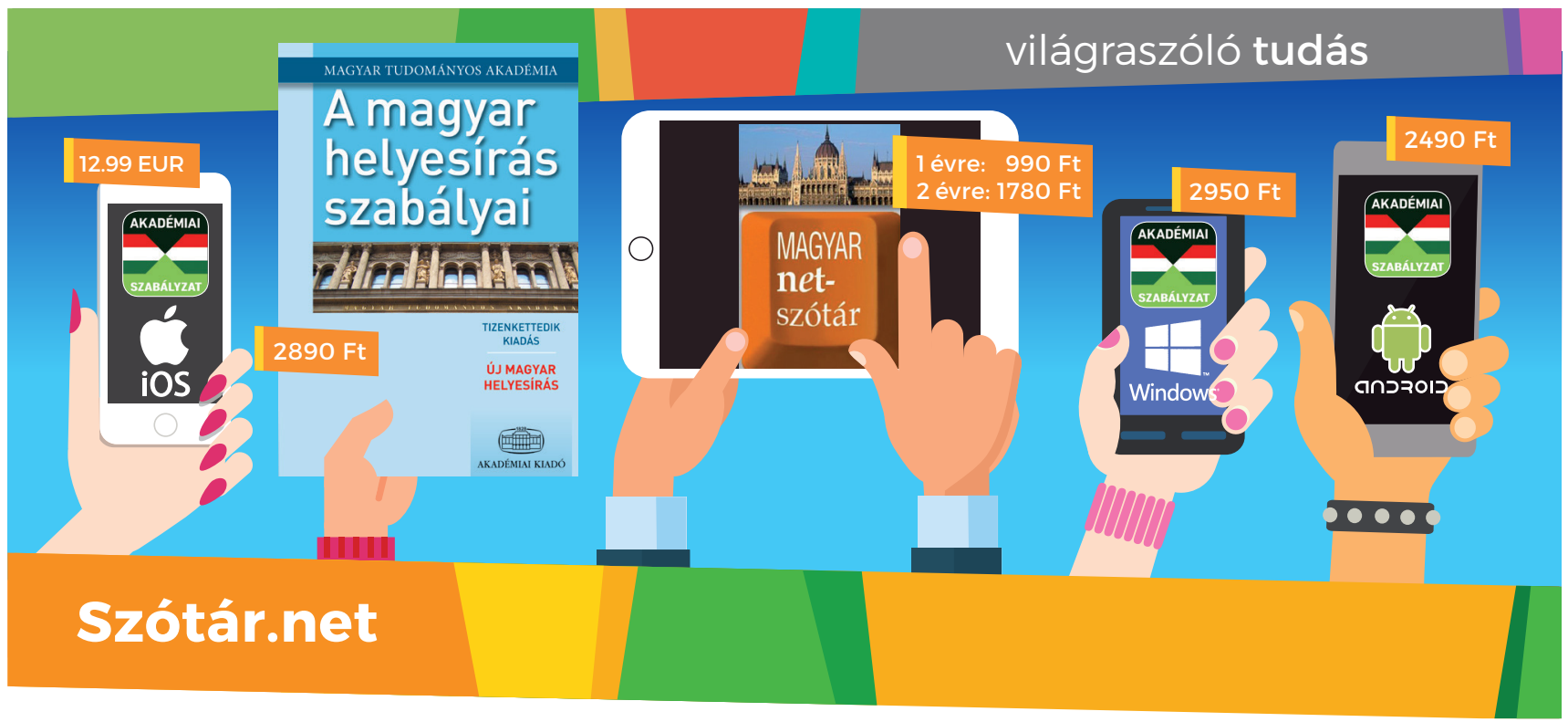

\section{A magyar helyesírás szabályai 12. kiadás}

\section{Mindig a keze ügyében!}

\section{- a Magyar Tudományos Akadémia szabályzata - 300 szabálypont példákkal \\ - szabályzat és szótár egyben

\author{
- a 11. és a 12. kiadás közti különbségek \\ felsorolása, példákkal \\ - tárgymutató
}

Keresse a könyvet a www.akademiai.hu oldalon, vagy válassza az online változatot és a mobilalkalmazást a www.szotar.net-en!

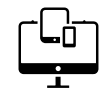

Szótár.net AKADÉMIAI KIADÓ 